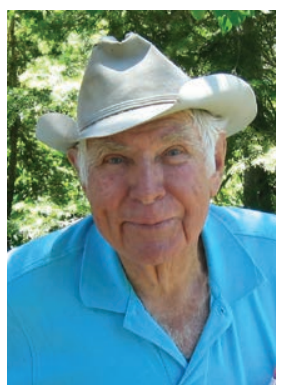

By Thad Box

\title{
Our Mission Impossible, a Land Ethic for Every Child
}

A $s$ the human population grows, less land is available to support each person. Both the land and the people who depend on it are changing. Land care professionals and the organizations they form must also change. Whether those changes are for better or worse depends on how well we understand and adapt to change.

I was a Texas A\&M graduate student when I attended the Society of Range Management (SRM) Convention in Great Falls, Montana. My young wife asked if I was sure I should spend our scarce money to become part of an organization that held its annual meeting in the middle of winter at frigid locations. Dad was equally skeptical. But I took my GI issued overcoat from mothball storage and went anyway. The meeting changed our lives.

Joe Pechanec, SRM's first president, sat next to me at the banquet. Giants named Chapline, Stoddart, Renner, Albertson, and Cook were real live people who took time to talk to a kid like me. I met students from other universities whose work defined our profession. Some are still my closest friends. Many are no longer with us, but their replacements continue to mold and define who and what we are as they adapt to changing and challenging times.

I attended most annual conventions until I passed age 75 . Then I left running our society to younger folks and sought a warm spot for a couple of months in winter. Although I'm often somewhere south of the equator when SRM meets, my thoughts are always with the hardy range people who gather at the coldest places during the coldest time of the year. Last February, SRM met in Orlando, Florida. Jenny and I attended for the first time in several years.

Those people organizing and managing the convention did an excellent job. The program had numerous sections covering a wide variety of topics dealing with rangelands. College teams from Canada, Mexico, and most western states brought youthful promise of things yet to come. There were events where old and young could mingle at informal venues. My hat is off to those who made the meeting a success. But even as we enjoyed an excellent program in the fellowship of friends, old and new, there was an underlying concern about our future.

Attendance at the convention was lower than previous years. Travel restrictions by government agencies probably reduced the number of early- and mid-career professionals. Distance from the homes of most SRM members may have lowered attendance of producers and retirees. For many years, SRM has had one of the highest percentages of members attending its annual conference of any profession. Lower attendance this year may be a reflection of declining membership.

The past president and charter members luncheon had only seven people this year. When we were told of the society's current condition-declining membership and spending from funds built in prior years - the graybeards shifted from remembering the past to thoughts for the future. The tone of the discussion was that the membership had to get younger and our profession more relevant to future land use. Much of the discussion was about education and partnering with other organizations with similar goals. 
During my plenary session talk I said only two percent of Americans live on the land; animal protein for human diets is primarily from fish, poultry, and swine grown in factory farms; the human population will double in 30 years, and most of the people will live in dense clusters called cities. I said that for us to live with and manage change, we would have to change ourselves. A member of the audience suggested I had preached a funeral sermon.

My response was that it was a birth announcement, not a funeral. His assessment was correct only if we make no changes in ourselves and our profession. We have a promising future if we accept the challenges of rebirthing ourselves into dedicated advocates for the land, not products provided by the land. Our own rededication must be coupled with educating about $98 \%$ of the population who have no contact with the land. Both these efforts depend on enlisting the best and brightest young people to our cause.

It is unlikely our recruits will come from the two percent of the people actually living on the land. The average age of most ranchers is beyond the childbearing age. Many of their children have established themselves in other professions. For the past several decades most new land care professionals were suburban or urban children who knew little about rangelands until they were young adults in college. Through an elective course, the encouragement of a professor, or a friendship with a natural resource student they found their way into land management.

Fortunately, we no longer have to recruit new professionals only from the male half of our people. The organizers of the Orlando meeting, the Outstanding Young Professional award winner, the top student in the combined range tests, the incoming president of our society, and the editor of this journal are all women. The December 2013 issue of Rangelands featured articles about women around the world who are active agents of change in land use.

As the human resource available for recruiting land care increases, some previously reliable programs for providing such people become weaker. Many leading universities have merged land management with other programs or realigned the program to address broad environmental concerns. There are good and valid arguments for making land studies part of general education. But in some cases, the broadening has been at the expense of training land care professionals.

Land care is far too important to postpone its teaching to the college level. We need to start with small children-and not just the children of people who appreciate the outdoors. And we can't leave it to scouting, SRM camps, and other volunteer groups. Land care should be taught in the public schools. This means someone must teach teachers and pro- vide materials that fit into curricula in every grade of every province or state in North America.

SRM has people interested and the expertise to do it. If we make this our primary goal, it could become our most important contribution during the lifetime of our society. To accomplish this goal, we must package our knowledge and experience into units that become incorporated into every grade. This suggests partnering with educational professionals familiar with politics of curricula requirements.

Some people are working on ways to accomplish this. The Welder Wildlife Foundation has developed a curriculum for rangelands to be used in Texas elementary schools. It is being field-tested in a number of schools. The University of Idaho and others have programs to teach teachers how to incorporate rangeland science into their classes. The Universidad de Sonora has a program for getting land management into primary schools. SRM members in Saskatchewan work with nonprofit groups to teach land care to youngsters. There are undoubtedly others.

A logical next step is to get people together to find out what is now being done and to compare successes and failures. President Jenny Pluhar has charged the SRM education committee with this task. That process is underway. A group guided by the Welder Foundation is meeting electronically to examine how the Texas effort could be used more widely. The program committee for the 2015 SRM convention is considering sessions and workshops on ways to get rangeland concepts taught in public schools.

Almost every section of SRM has programs to teach land care concepts to children. Most are camps or tours that teach rangeland concepts to kids who have some contact with the land. The land and our profession is better off because of them. But the real challenge is to get an understanding of a land ethic imbedded in the minds of every child. We cannot accomplish that alone. We must partner with teachers' groups who understand the politics of curriculum development and the ways to teach land concepts to kids of all ages. Joint annual conventions could be a good start.

Getting a land ethic in the mind of every child, if we choose to accept it, is our mission impossible. The survival of our profession may depend upon accomplishing that mission. It's not our profession, but the future of humankind that begs us to try.

\section{ThadBox, thadbox@comcast.net.}

Rangelands 36(3):18-19

doi: 10.2111/Rangelands-D-14-00014.1

(C) 2014 The Society for Range Management 